\title{
INTEGRATING MATHEMATICS LOCAL WISDOM BASED THROUGH WORKSHEET IN BILINGUAL PROGRAM
}

\author{
Nur Hidayanti' ${ }^{1}$ Melinda Yanuar $^{2}$, Ina Rohiyatussakinah ${ }^{3}$ \\ ${ }^{1,2,3}$ Universitas Banten Jaya \\ ${ }^{1}$ nurhidayanti@unbaja.ac.id, ${ }^{2}$ melindayanuar@unbaja.ac.id, ${ }^{3}$ inarohiyatussakinah@unbaja.ac.id
}

Received: April, 2020; Accepted: July, 2020

\begin{abstract}
Elementary school mathematics learning is generally taught classically by teachers. By using the lecturing method and the material is also general nationally. There is no regional element (local wisdom values) there is no technological element. In this study, researchers discussed the integration of local wisdom-based mathematics learning through the development of student worksheets with Banten culture in the bilingual program at the SDIT Assa'adah Global Islamic School (AGIS) Elementary School, Serang City. The aimed of this research is to introduce Banten regional culture to elementary school students in a bilingual program with Indonesian and English trough mathematic worksheet. Researchers also simultaneously introduce foreign languages that are commonly used. This study used Research and development in the ADDIE (Analysis, Design, Development, Implementation, and Evaluation) method. the population of research are IT AGIS Elementary School students, and the sample is grade 4 SD IT AGIS. In this study, researchers drafted a grade 4 bilingual mathematics worksheet. The results were validated by 3 experts recommended worthy of being tested on students.
\end{abstract}

Keywords: Bilingual, Banten Culture, Local Wisdom, Mathematics, Worksheet

\begin{abstract}
Abstrak
Pembelajaran matematika SD umumnya diajarkan secara manual oleh guru dikelas. Dengan menggunakan metode ceramah dan materinya pun umum secara nasional. Tidak ada unsur kedaerahannya dan juga tidak ada unsur teknologi. Pada penelitian ini, peneliti membahas mengenai pengintegrasian pembelajaran matematika berbasis lokal wisdom melalui pengembangan lembar kerja siswa (student worksheet) bermuatan budaya Banten pada program bilingual di Sekolah Dasar Ibtidaiyah Assa' adah Global Islamic School (Agis) Kota Serang. Tujuan dilakukan penelitian ini adalah untuk memperkenalkan budaya daerah Banten kepada siswa Sekolah Dasar dalam program bilingual dengan Bahasa Indonesia dan Bahasa Inggris. Peneliti juga sekaligus memperkenalkan bahasa asing yang sudah umum digunakan. Penelitian ini menggunakan metode ADDIE (Analysis, Design, Development, Implementation, Evaluation). Dengan populasi penelitian siswa Sekolah Dasar IT AGIS, dan sampelnya siswa kelas 4 SD IT AGIS. Pada penelitian ini, peneliti membuat draft modul matematika bilingual kelas 4 yang hasilnya divalidasi oleh uji ahli dengan hasil layak diujicoba kepada siswa..
\end{abstract}

Kata Kunci: Bilingual, Matematika, Lokal Wisdom, Budaya Banten, Worksheet

How to Cite: Hidayanti, Yanuar \& Rohiyatussakinah. (2020). Integrating Mathematics Local Wisdom Based Through Worksheet In Bilingual Program. Journal Of Educational Experts (JEE) 3 (2), 46-52.

\section{INTRODUCTION}

Mathematics is a science that plays an important role in life and is a useful branch of science for engaging and socializing in society (Purwanti, 2016). In fact, there are many problems faced, namely the ability of students to solve math problems is still low, this is because when learning mathematics students tend to memorize formulas, and only imitate the examples given, thus 
each time a different question is given, the student has not been able to work on the question even though the student has been given handbook (Anggoro, 2015). Currently, not only for senior high school (SMA) and junior high school (SMP) there are bilingual programs, but also at elementary schools (SD) there are also bilingual programs. One of them is mathematics. Mathematics in bilingual programs is still a very scary paradigm, because mathematics has a very abstract nature (Hasbullah, 2018).

The contents of student worksheets must also be able to develop students' thinking skills. This is in accordance with the research that has been done that student worksheets should be able to support and encourage students to be able to think, analyze, and compile the results of their own activities (Hernawati, 2015). Mathematics subjects in elementary school education units include the following aspects: (1) Numbers, (2) Geometry, (3). Data Processing. Number coverage includes numbers and figures, calculations, and estimates. This is stated in the syllabus for the fourth grade of elementary school at first semester in curriculum 2013. Using bilingual student worksheets in mathematics learning can improve students 'ability to solve math problems in English with an indicator of success in research is the increase in students' ability to solve math problems in English with the attainment of the minimum completeness criteria (KKM) (Zuraidah, 2017). ADDIE method developed by Dick and Carrey, developing local wisdom bilingual worksheet in Math that have been validated by material experts, media experts, linguists and trials, the average score is very good in the material category, the media gets very good scores and very good also in the field of language (Sandiyanti, 2018).

Student worksheets is an instruction sheet for students to carry out an activity in the learning process, as well as a list of tasks and a place to record observations (Astuti, 2017). The width of this activity is usually in the form of instructions, steps to complete a task (Majid, 2006). Adding student worksheets contains a set of basic activities that must be done by students to maximize understanding in an effort to form basic abilities according to indicators of achievement of learning outcomes that must be taken (Triyanto, 2015). Local wisdom should also be preserved to develop regional culture, but it is more often ignored in learning, only briefly conveyed to students, not discussing the roots of regional culture. This is only understood and cannot be applied in everyday life (Ulfah, 2018). Learning tools based on local wisdom developed in valid categories so that they are quite effective in improving students' problem solving abilities (Wahyuni, 2015). Furthermore, learning that is oriented towards local wisdom gives a more contextual impression in learning therefore students easily understand the material being studied (Fannie, 2014).

\section{METHOD}

The data analysis technique used in this research is descriptive analysis, namely by calculating the average score of the validity score of each validity indicator of the student worksheet and the average used response score. Validation score given by the expert as a result of validation. The feasibility of student worksheets developed from user response scores (on a small-scale trial). This research is a research and development (Research and Development). This study uses the ADDIE research model, namely analysis, design, development, implementation and evaluation (Gunaydin, 2016). The systematic process is represented by the acronym ADDIE, namely analysis, design, development, implementation, evaluation (Aldoobie, 2015). This research is in accordance with the ADDIE research stages, which begins with the analysis 
Covid-19

process and the evaluation process. The development design used in this study is ADDIE, describing the ADDIE design stages as follows :

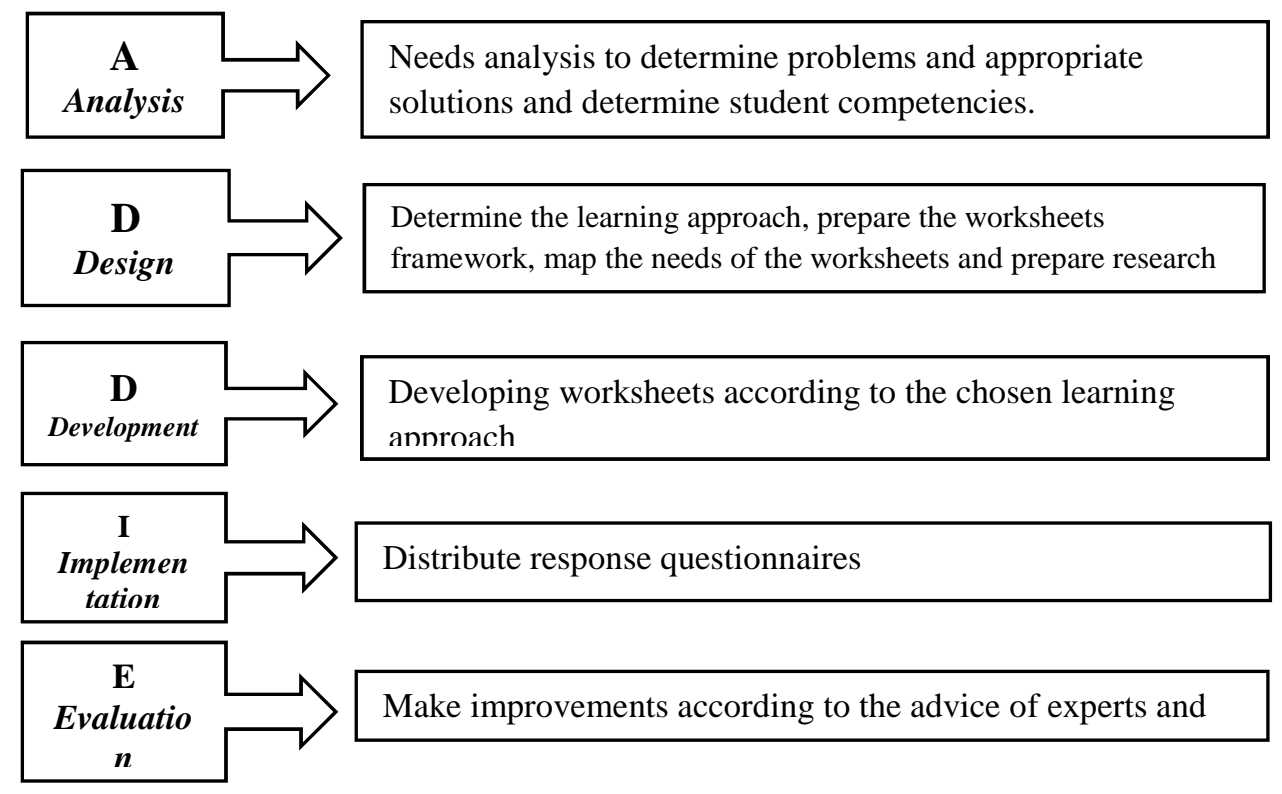

Figure 1. ADDIE design stages

At the analysis stage, the researcher conducted a learning analysis. it is found that the learning is centered on the teacher. The student worksheets made by the teacher used have not been able to fully assist students in learning objectives because the concepts proposed are still very general, the examples of stories presented do not contain elements of local wisdom that are appropriate to the child's learning environment. Based on the analysis, the use of bilingual mathematics student worksheet based on local wisdom is one way to overcome this problem. At the design stage, the writer determines the format and design. At the develop stage, the designs obtained from the design stage are developed into bilingual Mathematics Worksheets based on local wisdom. The response of teachers and students about the developed bilingual worksheets local wisdom based is good.

The implementation of this research and development, the researcher used two types of data collected, namely, quantitative data and qualitative data. The data collection technique used to obtain data on student responses to illustrated bilingual student worksheets used a questionnaire by distributing a G- form link.

Table 1. Guidelines for Questionnaire Assessment Scores

\begin{tabular}{llc}
\hline No & \multicolumn{1}{c}{ Category } & Score \\
1 & Very High & 4 \\
2 & High & 3 \\
3 & Low & 2 \\
4 & Very Low & 1 \\
\hline
\end{tabular}

(Source: Sugiyono, 2015) 
Furthermore, the calculation of each question item is carried out using the following formula:

$$
\mathrm{P}=\frac{\sum x}{m \quad s} \times 100 \%
$$

$\mathrm{P}=$ Percentage of eligibility

$\sum_{a}=$ Total score

The final step is to conclude the calculation results based on aspects by looking at table 2, bellow :

Table 2. Categories of the validity of the design student worksheet format

\begin{tabular}{cc}
\hline Percentage & Category \\
$75 \% \leq \bar{x}<100 \%$ & Very Good \\
$50 \% \leq \bar{x}<75 \%$ & Enough \\
$25 \% \leq \bar{x}<50 \%$ & Not Good \\
$0 \% \leq \bar{x}<25 \%$ & Very Not Good \\
\hline
\end{tabular}

The development product will end when the assessment score on this student worksheet has met the eligibility requirements with the suitability level of the material and design, which is categorized as very attractive. By having the following categories:

Table 3. Categories of validity of student worksheet contents

\begin{tabular}{ccc} 
T & Percentage & Category \\
1 & $3,25 \leq \bar{x}<4$ & Very High \\
2 & $2,50 \leq \bar{x}<3,25$ & High \\
3 & $1,75 \leq \bar{x}<2,50$ & Low \\
4 & $1,00 \leq \bar{x}<1,75$ & Very Low \\
\hline
\end{tabular}
follows:

The criteria for drawing conclusions on the developed student worksheet are defined as

a. Each component of the assessment for the student worksheet format is declared valid if the validity is high according to table 3 .

b. Each component of the assessment of the contents of the student worksheet is declared valid if each statement on the indicator gets a score of 3 and 4, the validity is high or very high according to table 2 .

Table 4. Criteria for LKS User Response

\begin{tabular}{ccc}
\hline No & Response Interval & Category Response \\
1 & $3,25 \leq \mathrm{R}<4$ & Very High \\
2 & $2,50 \leq \mathrm{R}<3,25$ & High \\
3 & $1,75 \leq \mathrm{R}<2,50$ & Low \\
4 & $1,00 \leq \mathrm{R}<1,75$ & Very Low \\
\hline
\end{tabular}

Practicality user response student worksheets based on local wisdom, seen from the responses of teachers and students to student worksheets. Student worksheets are declared fit for used if the user's response is in the high or very high category.

\section{Result and Discussion}

The development of student worksheets based on local wisdom that has been carried out show the following results: 
Covid-19

Table 5. The results of the validation of the student worksheet design format

\begin{tabular}{ccc}
\hline User & Average & Category \\
\hline V-1 & $\mathbf{3 , 3 0 5}$ & Very good \\
V-2 & $\mathbf{3 , 3 0 5}$ & Very good \\
\hline
\end{tabular}

Based on the expert validation above, design format of worksheet got average score 3,305 was very good criterion. It means that format of worksheet design was valid to be used as material development that propose by researcher.

Table 6. The results of the validation of the contents of the student worksheet width

\begin{tabular}{ccc}
\hline User & Average & Category \\
\hline V-1 & $\mathbf{3 , 3 7}$ & Very good \\
V-2 & $\mathbf{3 , 3 7}$ & Very good \\
\hline
\end{tabular}

Based on validation experts Questionaire, got average score 3,37 was very good criterion. It means that worksheet was valid to be used for $4^{\text {th }}$ grade students as their material, exercise and references in their learning. In this research and development, the researcher drafted material into bilingual worksheet of mathematic with local wisdom values and without disseminated to large group test because the pandemic of Covid 19, the student learns at home by daring and also the drafted need more critic to be great product.

Table 7. Results of validation of student worksheet user responses

\begin{tabular}{ccc}
\hline User & Average & Category \\
Teacher & $\mathbf{4}$ & Very good \\
Student & $\mathbf{3 , 6}$ & Very good \\
\hline
\end{tabular}

Score of questionnaires from teacher and students as user of development product delivered by G-form on Whatsapp given for teacher and students, it got average score very good criterion. it could be references for the researcher to be continue the worksheet development until disseminated and granted ISBN and HAKI and could be useful for students $4^{\text {th }}$ elementary school in Banten or Indonesia.

\section{CONCLUSION}

The development of student worksheets on bilingual mathematics subjects based on local wisdom can provide opportunities for students to increase knowledge and build creativity in learning English. Through this learning strategy, researchers make teaching materials that can help teachers in the classroom in providing material and students can easily understand the material provided by the teacher in class. In making student worksheets, researchers used expert tests for validation. As well as mathematical knowledge, the use of English, the context of the suitability of the use of animation, the suitability of the cover design. In this case, the researchers only make a draft student worksheet consisting of 2 chapters, namely the operation of counting numbers and multiples and a factor of a say according to the additional output in submitting a research grant proposal for novice lecturers. In addition, it will be continued in the next grant by making textbooks for grade 4 elementary schools, therefore that researchers can contribute creative works to the world of education. This is almost the same as the research which explains that the developed worksheets are declared valid where the validity of the student worksheet format is high. This is similar to research that describes the results of the feasibility test for teaching material products in the form of bilingual worksheets with a contextual approach both 
from the test of material experts, media experts, linguists, teachers and students that can be used or valid, therefore it can help teacher learning in class (Veny, 2014).

\section{ACKNOWLEDGMENT}

Appreciation and thanks to the Directorate of Research and Community Service (DRPM). The Ministry of Research and Technology / National Agency for Research and Innovation, which has funded the research activities for beginner lecturers (PDP) in 2020 with the title Integrating Local Wisdom-Based Mathematics Learning Using Worksheets with Banten Culture in the Bilingual Program at SDIT ASSA'ADAH GLOBAL ISLAMIC SCHOOL (AGIS) Kota Serang Banten. Thank you also to the Institute for Development, Research and Community Service, University of Banten Jaya for assisting in this research activity through research contract No. 042 / SP2H / LTT-MONO / LL4 / 2020.

\section{REFERENCES}

A. Majid. (2016). Perencanaan Pembelajaran. Bandung: PT Remaja Rosdakarya.

A. Sandiyanti and R. Rakhmawati M.(2018). "Pengembangan Modul Bilingual Bergambar Berbasis Quantum Learning pada Materi Peluang," Desimal J. Mat., vol. 1, no. 2, p. 157.

A. Ulfah and S. Trianingsih. (2018). "Keefektifan lembar kerja siswa tematik berbasis local wisdom terhadap karakter kerja sama siswa kelas 1 SD," Prem. Educ. J. Pendidik. Dasar dan Pembelajaran, vol. 8, no. 2, p. 161.

B. S. Anggoro. (2015). "Pengembangan Modul Matematika Dengan Strategi Problem Solving untuk Mengukur Tingkat Kemampuan Berpikir Kreatif Matematis Siswa," Al-Jabar J. Pendidik. Mat., vol. 6, no. 2, pp. 121-129.

D. P. \& K. Hernawati. (2015). "Pengembangan Lembar Kerja Siswa Materi Garis dan Sudut dengan Pendekatan Inquiry Berbantuan Software Wingeom," Semin. Nas. Mat. dan Pendidik. Mat., vol. 1.

H. Hasbullah, Y. Wiratomo, and E. Yuni Rahmawati. (2018). "Pengembangan LKS Pemecahan Masalah Matematika Bilingual Berdasarkan Strategi Metakognitif untuk SMP Kelas VII," JTAM J. Teor. dan Apl. Mat., vol. 2, no. 1, p. 31.

N. S. Astuti. (2017). "Pengembangan lembar kerja siswa (lks) pada mata pelajaran matematika siswa kelas x sma," vol. 1, no. 2, pp. 13-24.

N. Aldoobie. (2015). “ADDIE Model," Am. Int. J. Contemp. Res., vol. 5, no. 6, pp. 68-75.

R. D. Fannie and Rohati. (2014). "Pengembangan Lembar Kerja Siswa Berbasis POE," Sainmatika, vol. 8, no. 1, pp. 99-105.

R. D. Purwanti, D. D. Pratiwi, and A. Rinaldi. (2016). "Pengaruh Pembelajaran Berbantuan GeoGebra Terhadap Pemahaman Konsep Matematis ditinjau dari Gaya Kognitif," AlJabar J. Pendidik. Mat., vol. 7, no. 1, pp. 115-122.

S. Wahyuni. (2015). "Developing Science Learning Instruments Based on Local Wisdom To Improve Student'S Critical Thinking Skills," J. Pendidik. Fis. Indones., vol. 11, no. 2, pp. $156-161$.

S. Günaydin and A. Karamete. (2016). "Material development to raise awareness of using smart boards: An example design and development research," Eur. J. Contemp. Educ., vol. 15, no. 1 , pp. 114-122.

Sugiyono. (2015). Metode Penelitian dan Pengembangan. Bandung: Alfabeta.

Triyanto. (2015). Model Pembelajaran Terpadu: Konsep, Strategi, dan Implementasi Kurikulum Satuan Pendidikan (KTSP). Jakarta: Bumi Aksara. 
52 Hidayah, Mobile-Learning Feedback And Students' Self- Efficacy In New Normal Post Covid-19

Y. R. D. Veny Wuryaningrum, Nurmasari Sartono. (2014). "Pengembangan Lembar Kerja Siswa (LKS) Bilingual dengan Pendekatan Kontekstual pada Materi Sistem Reproduksi Manusia," BIOSFER, vol. VII, no. 1.

Y. Zuraidah and M. Enim. (2017). "MATEMATIKA BERBAHASA INGGRIS MENGGUNAKAN LEMBAR KERJA SISWA BILINGUAL DI SEKOLAH MENENGAH ATAS NEGERI 1." 